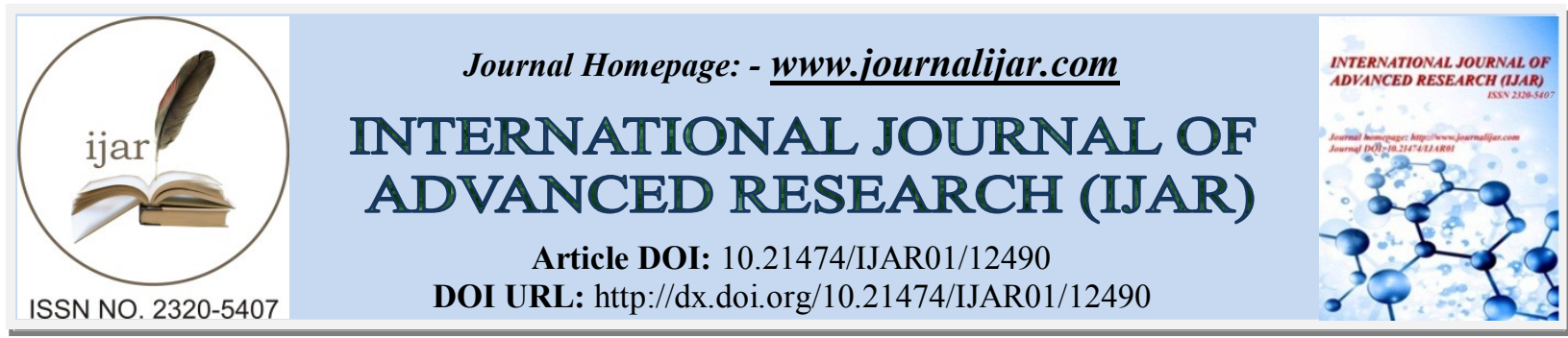

RESEARCH ARTICLE

\title{
FROM BUSINESS DISASTER TO PROFESSIONAL BREAKTHROUGH: THE COPING MECHANISMS OF FILIPINO MIGRANT WORKERS, A PHENOMENOLOGY
}

\section{Roberto C. Jacob MAT ${ }^{1}$, Guzman, Ebenezer I. ${ }^{2}$, Magtaka Cyrille Emir B. ${ }^{1}$, Rubin, Jef M. ${ }^{3}$, Turo Franco Emmanuelle P. ${ }^{3}$, Candaruma Alliah Venice D. ${ }^{1}$, Madriaga Francesca Viannca B. ${ }^{3}$ and Somera Jania Ann Claret $\mathbf{B}^{1}$}

1. Philippine School Doha, Doha, Qatar.

2. Research Development, Accreditation and Publication Office, PSD, Doha, Qatar.

3. Research Capstone Project, PSD, Doha, Qatar.

\section{Manuscript Info}

\section{Manuscript History}

Received: 15 December 2020

Final Accepted: 18 January 2021

Published: February 2021

Key words:-

Business Failure, Coping Mechanisms, Filipino Migrant Workers, Entrepreneur, Phenomenology

\begin{abstract}
Background: Some businesses, compared to million-dollar enterprises, fail to make an impact. As a result, some entrepreneurs resort to closing their businesses. To excel in their professions, they need to cope with business losses.

Method: This paper used a phenomenological design to understand the participants' lived experiences, particularly Filipino migrant workers who have experienced business loss, relative to the central question, "How do Filipino professionals cope with business loss?"

Findings: Filipinos displaying entrepreneurial characteristics (business mindedness, profit orientation, future planning) have desires to raise enterprises. However, entrepreneurial trials (e.g. management issues, competition issues, financial burdens) will be faced, which result in business losses. They coped with losses through entrepreneurial solutions, specifically career motivation and family motivation. Conclusion: Maintaining an enterpriseis never easy as it requires sacrifices, time, and especially money. Business disasters come with overwhelming consequences and complications. Nevertheless, after facing different challenges of experiencing business loss, former entrepreneurs can achieve breakthroughs. This research aims to help future entrepreneurs cope with predicted business losses. Recommendation: The researchers recommend considering other coping mechanisms to explore other options for future entrepreneurs. Furthermore, it is also recommended to focus on one business nature and one employment sector to achieve more specific findings.
\end{abstract}

Copy Right, IJAR, 2021,. All rights reserved.

\section{Introduction:-}

Improvement will always be present in this world where society is always changing. Problems and challenges appear every day in the lives of humanity, giving the significance of finding and discovering new knowledge. To find answers, curiosity should be present. 
Migration has become one of the common practices of Filipinos in recent years. Filipinos migrating to other countries has become a trend as the century passed by: in Ireland, for example, only 257 Filipinos were in the Republic in 1991, but this number increased to nearly 18,000 in 2007 and increased even further to over 20,000 in the year 2009 (interview with members of the Philippine Embassy, Dublin, 2009;Nititham, 2011). This has happened as it is assumed that this practice provides a stable source of income to help their families in the Philippines. However, once numerous factors have been considered (e.g. entrepreneurial mindsets, insufficiency in income, approaching retirement, and factors of similar nature), some people would find other alternatives when it comes to gaining income, and one of the main practices that Filipinos turn to is entrepreneurship.

Despite these efforts, as the number of businesses continues to increase, some will stand out, and some who won't. Furthermore, as entrepreneurship is one of the more common practices of gaining income nowadays, it is expected that the other businesses will result in numerous trials not only competition-wise but also internally, with management issues and financial burdens arising within the business. The relevance of research to this study is to help understand the challenges of business loss and how future businessmen can recover and be successful through it.

This research was conducted to discover more about the lived experiences of the Filipino migrant workers who came from business disasters. The researchers wanted to look more into the coping mechanisms of former entrepreneurs in order to find out how they achieved their professional breakthroughs and success through their failed business ventures. This paper also magnifies the understanding that failure is also a significant part of the entrepreneurial process which leads to coping and learning. According to Cope (2011), recovery and re-emergence from failure are unique learning mechanisms which promote a higher range of learning outcomes. This form of research writing is essential in studying the coping mechanisms of failed Filipino businessmen towards success.

In raising a business, it is expected that there are many challenges that will arise. This study aimed to look for how Filipino migrant workers coped with business losses.

\section{Methods:-}

Gathering the necessary data for this study was accomplished by performing semi-structured interviews. The questions that were asked related to the central question and the responses were used in order to produce the recurring themes, which are found in the simulacrum.

\section{Research Design:}

This qualitative research study uses a phenomenological research design, which was used to capture the lived experiences of the participants. Phenomenology focuses on consciousness and the content of conscious experience, such as judgments, perceptions, and emotions (Balls, 2009). Phenomenology also focuses on humans as embodied beings, meaning they experience life through their physical bodies. Phenomenologists want to know what the experience was like to live it, not just the person's reaction to the experience (Munhall, 2007). In addition to philosophy, phenomenology as a research method is used in psychology, education, and in health care (Connelly, 2010).

With the use of this research design, the researchers are able to fully capture the lived experiences of Filipino migrant workers who have experienced business loss.

\section{Research Locus and Sample:}

The research study was conducted in Philippine School Doha, a Filipino community-based learning institute in the State of Qatar. The institute has been known for its quality education and for serving the Filipino community in Qatar. The researchers chose this locale due to its accessibility.

The researchers also chose seven participants who meet the following criteria: Filipino, had previously lost a business for whatever reason, and is currently employed outside of their provincial origin. The qualitative research study used the purposive sampling strategy in order to select the participants that will be necessary in order to properly conduct this study. 


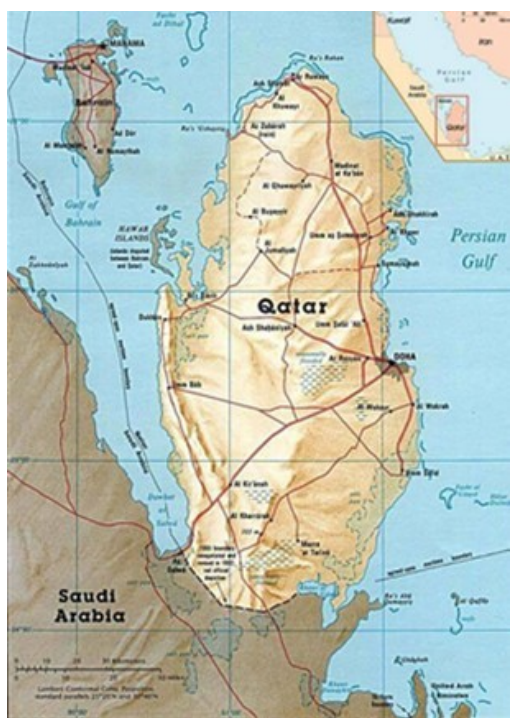

Figure 1:- Map of Qatar.

\section{Data Collection and Ethical Consideration}

The study was conducted through a semi-structured interview by giving the participants a Robotfoto and using twenty-five developmental questions, which will guide as data.

The Robotfoto was given to the participants in person and the developmental questions were used to capture the lived experiences of Filipino migrant workers.

The data gathered was then transcribed verbatim with the use of a voice recorder wherein audio recordings were saved. The researchers assure that their answers will only be shared amongst the researchers in order to maintain the confidentiality that the participants are promised.

The semi-structured interview was done by scheduling the interview. The researchers asked for approval from the interviewees, which was done by handing out consent letters.

\section{Data Analysis:}

The researchers have found an inductive method in developing their themes. They have utilized the following methods in order to collect their data: (1) conduct a semi-structured interview from the selected participants; (2) transcribed the participants' answers verbatim by replaying the voice recording; (3) converting the participants' answers from the participants' point of view to the researchers' naïve understanding of their responses; (4) eliminating irrelevant answers and grouping relevant answers, formulating different categories and themes with the use of a dendrogram, and (5) creating a simulacrum as a visual representation of the findings gathered.

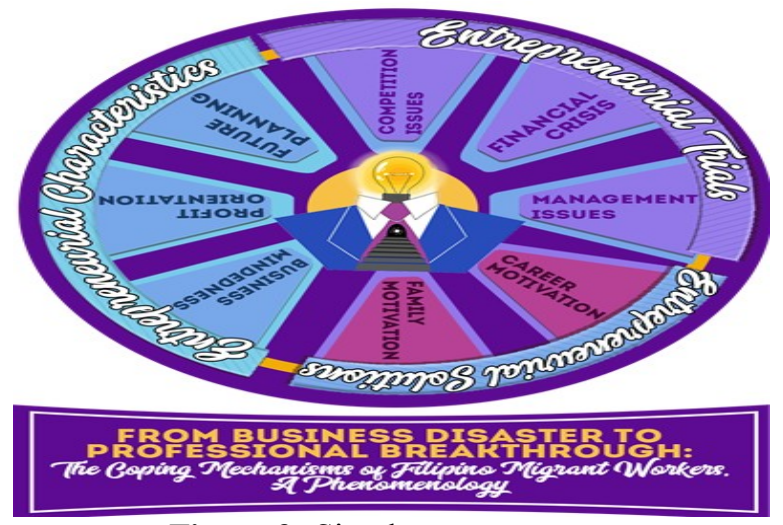

Figure 3: Simulacrum 


\section{Factors that Affect the Coping Mechanisms of the Entrepreneurs Towards Business Loss: Findings:}

Though a high number of fresh graduates hail from the Philippines, the number of employment offerings in the country do not satisfy the demands of many. Hence, many Filipinos turn to entrepreneurship as a way to guarantee that they would gain profits. However, for a multitude of reasons (e.g. arising competition, incompetent management, and the like), it happens that profits earned would not be sufficient to maintain the business, thus resulting to the entrepreneurs making the painful decision to close their business.

Business losses are so much more than closing business operations, as a business is not only a name. It involves other aspects as well, such as time, money, inventory, and other components. Because of the great number of losses that comes with business loss, it can result in numerous psychological setbacks. As a result, the idea of entrepreneurship is set aside, if not eradicated completely, and Filipinos turn to employment opportunities, primarily those in countries outside of the Philippines.

This current study explicates the phenomenology of the Filipino migrant workers about their coping mechanisms towards business disaster. It outlines how the former entrepreneurs have risen from their business losses with their adaptive strategies such as motivations, lessons, and solutions that they have learned and realized, achieving professional breakthroughs. The objective of this study is to distinguish the different coping mechanisms of Filipino professionals in order to produce more business strategies or solutions of aspiring entrepreneurs. The present study can also be an academic help for aspiring businessmen to plan ahead once business losses arise.

As a result of organizing the participants' introspections and through reflecting on their ideas, the themes were formed and divided into three which are illustrated in Figure 3. These are: (1) Entrepreneurial Characteristics, which consists business mindedness, profit orientation, and future planning; (2) Entrepreneurial Trials, which incorporates the management issues, financial burdens, and private matters; (3) Entrepreneurial Solutions, which includes family motivation and social activity. The simulacrum is formed with a variety of design and colours which is accompanied with different symbolisms. Firstly, the simulacrum is formed in a wheel-like structure which explains that life is still a wheel and is a never-ending cycle. Losses, failures or disasters are inevitable in life, there will always be a time where one is in its lowest but eventually, life should continue, one should rise up and have to be able to overcome the losses. Secondly, the logo in the middle consists of a light bulb, stairs and the physique of a professional. The light bulb represents the entrepreneurial mindset of the professionals. In addition, the stairs towards the light depict the endless inspiration and motivation in order to reach one's goal.

\section{Entrepreneurial Characteristics:}

Having the right mindset is important when it comes to raising a business. Business mindedness refers to the ideologies and mindsets of an individual to raise a business. Individuals choose to become entrepreneurs for a range of reasons, financial or non-financial (Abreu, Oner, Brouwer, \&Leeuwen, 2019). Most people find that raising a business can have its challenges, but entrepreneurs enjoy facing these challenges, who even use these challenges as motivators:

"I am interested in businesses that can bring services and benefit my family. I am also aiming to have more branches which motivates me, especially since the business bears my name." (R2)

"My interests in business include working and management. I would also like to stand alone and become the boss of my own business." (R4)

"My first motivation was marketing. Currently, I am operating a mini-store, which sells products that I deem to be essentials. Back then, however, I realized that a computer shop is a need for students. It also became an advantage that it was located near schools." (R6)

Entrepreneurs are also looking for ways to improve their businesses. They are constantly coming up with new ideas and taking risks:

"We decided against continuing the business at this time. However, we plan to raise another business in the Philippines related to the business we originally raised." (R1) 
"I prefer the situation during the peak of my business because I was constantly coming up with new ideas." (R5)

Some of the participants even continue to recognize their passion and determination to raise an enterprise, even if they have experienced shutting their businesses down. They often look for alternatives and solutions in order to keep their business afloat:

"We tried our best to revive the business and we tried to get back the past." (R2)

"We attempted to look for another spot." (R2)

"I showed people that I still wanted to raise a business. I did not want to stop." (R2)

"I invested some money in a small business such as a sari-sari store." (R5)

"I thought of a lot of solutions, such as selling products that are on demand." (R6)

Another evidence of business-mindedness is observed when the participants were willing to learn some lessons in order to become better entrepreneurs:

"If you are going to put up a business, it should be you or the family who manages it. You should also have a contingency plan just in case everything goes downhill. Additionally, you should think of your intentions as to why you plan on raising a business." (R1)

"First of all, consider the location of your business. Look for an area that you can officially claim ownership to, and where you can always return to." (R2)

"I realized that starting a business is not easy if you are not prepared, so it is important that you are knowledgeable and hands-on in the business you will enter." (R7)

"I learned to be more patient, considerate, and innovative. I also learned to manage my time between my clients and myself." (R5)

A desire to gain profit is one of the main reasons as to why people decide on raising a business. Profit-orientation is the monetary focus of accumulating personal wealth, as a consequence of a permanent maximization of profits (Kollen, 2016). Most people who have a stable 9-to-5 job turn to entrepreneurship, believing that raising a business can help them earn additional income at a faster rate:

"I was previously an OFW. I was motivated to raise a business because I realized that it would help me gain more income when I go back to the Philippines." (R6)

"I realized that when I retire, I need another source of income." (R7)

"I already had a job so I continued working in order to contribute to the economy. Although I invested a lot in a failed business, it was only money that was lost." (R7)

"I decided to use my career as a solution as it helped me earn money." (R7)

"Since my husband works here, I can consider it as an alternative for income." (R2)

"My first alternative was to find a job as a kitchen manager. I trained in the Food \& Beverage sector in TESDA." (R3)

"I budgeted all of the money I had since profits were no longer considered." (R4)

"I considered it so that I can still continue making more money." (R4) 
"Yes. I can earn more profits in a quicker amount of time if I have our own business.” (R6)

"We were able to move on from those setbacks. Due to this, we are now financially stable." (R1)

"I realized that when we go back to the Philippines, we still need to raise a business in order to keep money flowing since we won't be here for a long period of time." (R2)

In addition to that, every profit-oriented entrepreneur is driven by his/her long-term goals given that his/her current financial situation would not remain for a long time unless a business has been established:

"I was previously an OFW. I was motivated to raise a business because I realized that it would help me gain more income when I go back to the Philippines. ” (R6)

"I realized that when I retire, I need another source of income. (R7)

"I realized that when we go back to the Philippines, we still need to raise a business in order to keep money flowing since we won't be here for a long period of time." (R2)

Moreover, the experiences and past learnings that they have encountered are also the factors that drove them to seek and grow more profit:

"I decided to establish a business when I came to the realization that I needed to earn more money, since I learned that businesses can help me increase my earnings." (R4)

"Money, plus the business to grow by improving margins and the customer base." (R3)

"I already had a job so I continued working in order to contribute to the economy. Although I invested a lot in a failed business, it was only money that was lost." (R7)

"We were able to move on from those setbacks. Due to this, we are now financially stable." (R3)

Migrant workers also have the desire to plan for their future. Future planning refers to an individual's capabilities and desires to think ahead for future events, such as unpredictable incidents, upcoming retirement, and the like. Although they may find a sense of stability in their jobs through employment, there is a risk of losing their jobs due to unforeseeable circumstances, which is why they turn to raising a business, which can be another form of financial stability, which they can continue working on once they reach the retirement phase. As those who work overseas also seek motivation from their families, they also committed to raising businesses in order to provide stability to their loved ones, specifically to their children:

"I decided to put up a business when I realized that I wanted to have a comfortable life when I grow old and retire." (R1)

"We considered raising another business for our children's future." (R2)

As they realize that entrepreneurship has its setbacks, businessmen and businesswomen experience business losses. As a result, some of them already have plans to raise other businesses:

"We did consider raising another business. (R1)"

"I had plans to do another business (R3)"

"Yes. When there is a business failure, there are some lessons that can help me re-evaluate all mistakes so that I can raise another business. (R5)”

"I accepted the learnings. I now know what to do once I decide to raise another business." (R1) 
"I accepted the learnings because if you don't, you are bound to make the same mistakes again." (R2)

"I was able to accept these learnings because it will help me become successful with the next businesses I plan to raise in the future." (R6)

In order to successfully raise a business, one must have the passion and the determination in order to succeed.

\section{Entrepreneurial Trials:}

Arising problems from other businesses seems to have an effect on all entrepreneurs relating to their goals on having and maintaining a successful business. Competition issues refer to the problems and issues being dealt by small businesses once other businesses related to their enterprise's nature is established.

In managing and maintaining a business, competition is bound to happen, and with competition comes the struggle to be consistent in all aspects including its market power, thus creating solutions that would become issues with the inflation and decrease of prices, which in turn would run the risk of the business failing:

"I had so many struggles, but the struggle that struck me the most is the emerging competition. I just accepted that I cannot control the competition and that it will always be a part of struggling." (R2)

"My struggles include stiff competition with Chinese competitors and customer bases. We adjusted our sales during the "lean months", which ranged from June to October." (R3)

"Some of these solutions failed immediately, but some were temporary solutions. We had to repair the cash flow from the business since we expected it due to emerging competition." (R3)

Another concern that businesses need to address is the risk of gaining losses instead of profits. Whether the business gains profits or not, they still have to pay fixed costs which could have been owed to other enterprises. Financial burdens refer to the struggles that one has when they need to pay up these fixed costs.

The conventional view of business financing was that a firm's access to external capital would be limited by informational opacity. This would force business owners to rely on their own assets and on financing from friends and family during start-up and initial operations. (Miller, Hoffer \&Wille, 2016) In managing a business, problems such as losses are inevitable. As a result, entrepreneurs look at other means in order to maintain an income:

"We were able to focus on our jobs, which helped us deal with the extreme financial issues. "(R1)

"The issue with finances was dealt with, and resolved, slowly." (R2)

"I prioritize my job because I need to save more money for a second business." (R6)

An entrepreneur, in his/her daily life, has to allocate his/her finances to numerous needs both within the business and outside of the business. However, there are moments when they make just enough money to live in the most basic rations. In addition to making money that just suffices his/her family's needs, there are some instances where he/she experiences issues with customers not paying up once told to, which becomes a massive liability as time passes by:

"The income I was receiving when I was working for my business was just enough to sustain myself and my family." (R3)

"I allocated some money for personal use and some money for family use." (R5)

"We decided on tightening our budget and thinking twice before spending our money" (R4)

"I encountered issues with most of my clients not being able to pay their debts. We tried to contact our clients in hopes that they can pay their debt as soon as possible." (R5) 
"The income I was receiving when I was working for my business was just enough to sustain myself and my family. “(R3)

Some participants find a way to pay their financial issues with help of their close friends or family and spend their savings. They often find a way to pay for their financial issues to make the business run again:

"Since my wife was here before I was, she helped my family and me solve the financial issues we had" (R3)

"Get a job. Keep the current money flowing for the family." (R3)

There are also instances wherein entrepreneurs do gain profit, but because of the costs that are associated with the business, the profit that is earned instead goes to settling those costs:

Additionally, a business heavily relies on managers in order to keep it afloat, but there are many instances where business management falls apart. Management issues refer to the issues that concern management which negatively impact the business.

Although entrepreneurs have the desire to raise a business, some fail to realize that a business will not flourish without proper management:

"I have a lot of interests in business. Unfortunately, they were overshadowed by issues with time and management." (R1)

“We struggled overcoming certain management issues.” (R1)

"Since I am working here in Qatar and the business is in the Philippines, I was not able to manage it properly." (R4)

"There were a lot of issues such as mismanagement and location issues. I felt enraged and disappointed because I invested a lot of money in the business and it went nowhere." (R6)

"There were so many things that contributed to the business failure (e.g., the machines used were not thoroughly taken care of). Instead of earning profit, money was put on fixing those machines. I also decided to replace the people that are physically there to run the business since I cannot be there to do so. " $R 7)$

"I had plans to do another business. Unfortunately, I was struggling with managing all of my priorities." (R3)

Many businessmen realize that working on the way that his/her business is managed can greatly impact the business's future:

"I learned to heal as time goes by. I also realized that I should be the one to manage my own business. "(R6)

"I learned that raising a business is really challenging, but the risk will pay off if it is managed properly." (R7)

"I learned to be careful when raising a business. I learned not to make hasty decisions and to pick the right person that is committed to raising the business." (R6)

Even if an entrepreneur has the passion to raise a business, there are certain issues that will definitely arise, such as management issues, competition issues, and financial burdens. Due to this, he/she needs to work on solving these issues in order to keep his/her business afloat.

\section{Entrepreneurial Solutions:}

A businessman experiencing enormous trials is a normal situation in the world of entrepreneurship. These trials cause numerous consequences, the heaviest being business loss. It is normal for entrepreneurs to grieve the loss of his/her business. However, he/she is not expected to grieve forever, he/she is expected to do something to revive the business and become successful. Therefore, they turn to numerous mechanisms which will help them not only move 
on from the business failure, but also keep gaining profit. Entrepreneurial solutions refer to the solutions that an entrepreneur applies in order to cope with business loss.

One of the main solutions that an entrepreneur works on is staying committed to working as a regular employee instead of becoming an employer, which is observed when he/she is working on his/her own business. Career motivation refers to an entrepreneur's desire to continue working in order to maintain a method of gaining income:

"My first alternative was to find a job as a kitchen manager. I trained in the Food \& Beverage sector in TESDA." (R3)

"I worked as a nurse." (R7)

Although some entrepreneurs completely dedicate their time to working on their business, some decide on entrepreneurship as a second endeavor. Normally, these people choose to raise a business in order to support the income that they are already gaining from working as an employee in a certain company. As a result, if their business results to ruins, they already have a job, which they use as a source of income that they can rely on:

"I already had a job so I continued working in order to contribute to the economy. Although I invested a lot in a failed business, it was only money that was lost." (R7)

"I was able to prioritize my own job now that I am currently here in Qatar." (R4)

"It was not hard because I have a career outside of my business." (R7)

"I decided to use my career as a solution as it helped me earn money." (R7)

"I face these issues properly. I continued working hard in order to save up once more and to sustain my family's needs." (R6)

Even though employees focus on their specific careers as a source of income, some are still eager to raise another business. As a result, they use their current jobs as a way to gain more profits and consider raising another business:

"I learned to move on and pick myself up. One of the things I did in order to overcome such loss was to come to Qatar because I had to keep going." (R3)

"I prioritized my job because I needed to save more money for a second business." (R6)

Another way that entrepreneurs cope with business loss is by spending quality time with their families. The family is the support system of an individual, so they are often the ones that an individual turn to. Menges, Tussing, Wihler, and Grant (2017) state that family motivation is a special case of prosocial motivation - the desire to benefit others (Grant, 2008a) - where employees are driven to expend effort in order to take care of their spouses and dependents. Often, the members of their immediate family would do whatever it takes in order to help the individual cope with a loss as enormous as a business loss:

"I did. I spent it with my family and we were able to do things we weren't able to do back then." (RI)

"I spent quality time with my family. I was also able to enjoy myself, which helped me forget about the business failure." (R5)

"At first, they were not affected as much as we were, but they supported us as time went on." (R1)

"They told me not to doubt myself and continue on." (R2)

"There were some who were angry about the situation, but there were some who decided to have mercy and give me the motivation I needed to move on from this setback." (R4) 
"They were inspired when I told them my story and they were able to acquire some lessons from my experiences." (R5)

"They talked to us and they convinced us to raise another business." (R1)

"They motivated me to do better. We also bonded a lot more." (R4)

"They gave me moral support. They encouraged me not to give up in my own endeavors and create innovations." (R5)

Other solutions, such as spending time with other groups of people (e.g. the employees of the failed business), were also considered:

"Yes. I spent it with my previous employees since they also lost their jobs. Ifelt like communication is still key since it motivates all of us." (R2)

"I kept myself busy by being physically involved with a certain group of people." (R4)

Once they are able to apply the aforementioned solutions, they often result to looking forward to a better life:

"I prefer my current situation because I believe that my employment situation is much better and I get to spend more time with my family." (R1)

"I prefer both situations, since I believe that life goes on. I feel like I did not lose anything since I still have my family that I can see as motivation and as a support system." (R2)

A lot of entrepreneurial trials are going to arise, but entrepreneurs continue to find ways in order for him/her to not only solve the trials, but also cope with the extreme losses that come with the solutions one approaches.

\section{Discussion:-}

According to the data from Russian Longitudinal Monitoring Survey (RLMS), approximately one in ten people in Russia tried to launch and run a business in 2012, and somewhat less than half of these succeeded (Kozyreva, 2015; Mannila\&Eremicheva, 2018).Catastrophe can strike at any moment. For a small business, the impact of such an event could be devastating, and it's important to be prepared for potential events (Johnson, 2019). With the increased number of natural disasters comes an increase in business losses and business interruptions. While policyholders can protect themselves by purchasing "all risk" insurance policies, certain causes of losses will still be specifically excluded or only available under specialized endorsements or policies (MacLaren, Maloney, \& Phillips, 2017). Despite assertions and considerable technological breakthroughs in decision support technologies, half of all decisions made within firms fail to achieve the desired outcome (Nutt, 1999; Amankwah-Amoah, 2014). and business failure remains a regular occurrence often traced to decisions made within the firm (Dovey and Fenech, 2007; Amankwah-Amoah, 2014). The majority of business exits are either ownership changes or closures unrelated to the financial position of the business (for example, when the owner retires or seeks a different lifestyle). The remainder can be broadly classified as 'business failures' (Bickerdyke, Lattimore, \& Madge, 2000).

Once an individual experiences a business disaster, he/she needs to look for alternatives in order for them to earn an income. Although some solutions have been pondered on, the loss of something as priceless as a business can weigh heavily on an individual. This study was sought to see the coping mechanisms of Filipino migrant workers who have suffered a business disaster and are now experiencing a professional breakthrough in their own respective fields and careers.

The Philippines is known for its massive, diverse, and experienced workforce, yet a higher ratio of skilled Filipinos would rather leave their home country, seeking greener pasture in the foreign land. Filipinos tend to migrate to other countries due to the expectation of both a higher income and a better lifestyle, which will help them enable means of family advancement by sending home remittances (Tigno, 2018). 
Overseas Filipino workers (OFWs) have been considered as heroes by the Philippine government (Uy-Tioco, 2007). Having luxuries such as houses, cars, jewelries, and the like, are common to those employed in different countries. However, unlike the expectation that has been set by many people. working overseas is not as glamorous as it seems. The reality being faced by most OFWs is that they also face different challenges in their respective host countries, aside from leaving their families in the Philippines to have a better future. The challenges OFWs face include, but are not limited to, communication with their families back in the Philippines, financial strains, unfamiliar work environments, and the like (Bautista \& Tamayo, 2020). These factors, along with other reasons which will be discussed in the following paragraphs, are considered some of the reasons as to why employees make the bold decision to venture into entrepreneurship.

\section{Entrepreneurial Characteristics:}

In organized macrocosms, human beings have numerous needs in order to get around, such as food, shelter, and other similar needs. In order to fulfill these needs, business institutions are established, which will help them guarantee provision of those needs.

Every business strives to achieve an outstanding performance. Business firms wouldn't be able to survive without superior performances. Thus, it is essential to investigate the impact of factors that contribute towards the success of a firm. (Sajilan, UlHadi, \&Tehseen, 2015). Entrepreneurs are independent business protagonists. Schumpeter (1911) states that these are the key drivers of social and economic advancements. Schumpeter also emphasized their skills and abilities in the independent development and implementation of ideas and pointed out their innovative power, which encompasses the creation of new products, production processes, organizational structures or alternative distribution channels. Drucker (1986), Shane and Venkataraman (2000), and Spinelli\& Timmons (2008) regard making use of business opportunities as a main goal of entrepreneurship. The society wouldn't prosper the way it did without entrepreneurs, as they play essential roles in all of society's subsystems. This does mean that anybody can show the same levels of activity as entrepreneurs (Faltin, 2015; Lindner, 2018).

Entrepreneurship literature focuses on three major steps and processes for entrepreneurial development: (1) Discovery or opportunity identification (Alvarez and Busenitz, 2001; Ardichvili et al., 2003; Eckhardt and Shane, 2003; Shane, 2003; Zelekha, Yaakobi, \&Avnimelech, 2018); (2) Opportunity (problem-solution) validation and development (Blank, 2013b, Blank, 2012, Blank, 2013a; Ries, 2011; Sarasvathy, 2001, 2009, Zelekha, Yaakobi, \&Avnimelech, 2018); (3) Execution or determining and allocating resources (Alvarez and Busenitz, 2001; Brush et al., 2001; Eckhardt and Shane, 2003, Zelekha, Yaakobi, \&Avnimelech, 2018). Early stages of entrepreneurial development focus on the following: customers, suppliers, employees, partner-investor relationships, and trial and error processes, which are all reliant on different psychological aspects (e.g. alertness, empathy, cooperation, accountability, and other similar characteristics) However, latter stages focus more on determination, ambition, open-mindedness and peculiarity, challenges, and creativity. These are therefore more related to personality traits as they are related to internal processes (Zelekha, Yaakobi, \&Avnimelech, 2018).

A shift from traditional to modern in business management is seen in both developed and developing countries. However, in 2019, some African business leaders were deemed less competitive due to the continuous usage of traditional business management practices and marketing strategies, which fail to incorporate modern and more advanced innovations (Denousse, 2020). Ever since the beginning of the Internet era in the mid-1990's, firms have been exploring methodologies on how to operate a business and achieve their goals. This has led to a branching of scholarly literature on business models (Massa, Tucci, \&Afuah, 2016).

Entrepreneurship is valued in society, especially since it is a vessel of possibilities that create change (Anderson \&Gaddefors, 2017). As entrepreneurship is a force for creating a better world, entrepreneurs work on new opportunities, albeit with a risk of failure, which they are willing to take (Roberts, 2012). Moreover, the value of entrepreneurship continues to be emphasized in an international setting, especially considering the decline of central economic systems. Trends toward reducing the government's domination to an economy puts the entrepreneur in the center of economic guidelines and policies as they are the sole actors who make the marketplace work by starting, maintaining, and growing the businesses in any scale (Akin \&Demirel, 2015). Furthermore, entrepreneurship has strong associations with economic processes and growth. Its importance to a region's prosperity has been documented in literature, business publications, and others., which is why its increasing awareness has encouraged government leaders to enact enterprise-friendly communities. At any given timeframe, an impactful number of 
young people seem to grow interest in entrepreneurship, but fail to actually begin pursuing their dreams due to lack of financial resources and aids (Badal\&Ott, 2015; Mahto\&Mcdowell, 2018).

On another matter, profit is crucial to every business since it is essential from its starting point as a capital for investment, up to its continuity, growth and future returns. It is one of the most important things to consider in a business to thrive. "Profit then is a legitimate measurement of the value of our effort." (Pollard, 2017). Consecutively, a study reported by Iskandar (2017) shows that capital, profit and dividends concurrently have a significant influence on the capital structure, while partially affecting the Capital Shares Purchase Intentions.

Handy (2002) firmly stated that the share price is the metric for a corporation's prosperity. He propounds the idea that the main objective of a business "is not to make a profit, full stop" but rather to be profitable in favor of the entrepreneurs, their loved ones and the people close to them. Furthermore, the idea of making money as the principal target of every enterprise has been affirmed by many scholars. "This shareholder wealth maximization objective is justified on the grounds that it maximizes social welfare." (Jones \&Felps, 2013).

According to Jensen (2002), an influential argument in business ethics and economics, firms are normatively required to maximize their contributions to social welfare, and the way to do this is to maximize their profits. In other words, it is said about increasing profit that corporations and their managers should maximize profits because this is the course of action that will lead to an 'economically efficient' or 'welfare maximizing' outcome. However, following researchers argue that "even if firms are required to maximize their social welfare contributions, they are not necessarily required to maximize their profits." In addition, maximizing profits is not the only main course of action for economic efficiency and the 'personal sphere' commentary should also be given recognition. (Robson, 2019; Hussain, 2012).

Customarily, problems between profit-maximizing and achieving other purposes have been occurring to many businessmen regarding their central objective. At present in today's corporate world, profit motivation with further pursuits are now being situated and aligned by countless emerging companies through the innovation of new purpose-driven business models. It is reported that the two objectives, at this moment in time, can have a joint reinforcement with each other to eliminate conflict in determining the business goal which can even be a catalyst towards a competitive advantage (Osterwalder\&Pigneur, 2010). Additionally, the innovation demand placed on both profit-driven and mission-driven organisations is steadily rising in the face of changing technological and social paradigms, set against a generalised atmosphere of fiscal austerity. Hence, mission-driven organisations have undergone a series of transformations in order to find new revenue streams and to better serve their beneficiaries (Cipriani et al., 2020).

Shareholder organizations are built on the affiliation of contributed capital (Ninkovich, 2008). The investors are the owners who expect returns on the capital invested whereas they benefit from shareholding in terms of dividends and the increase of share value. Further, a main advantage of the public business is that the owners earn their share of the company's stock value as soon as they sell their shares. The stock valuation of the firm is also a concern of investors.

Business organizations settle on a plan of action on profit- maximization in order to achieve escalation of the total profit through diversification and become relatively mature in the industries where they are currently competing in. It can be observed that profit-maximizing actions done by companies contribute to the overall profit growth due to the distribution of these capacities across several sectors. Due to the presence of different assets and potentials which need to be apportioned, profit-maximizing diversification decisions are important to be considered especially based upon opportunity cost. Following this gives a rational implication about the division between total profits and profit margins (Levinthal\& $\mathrm{Wu}, 2010$ ).

Entrepreneurs often do not realize the significance of strategic planning for their own businesses. They are often faced with overloaded works that arise from their everyday business practices. Companies should have well-planned and detailed primary strategic documents like a business plan. According to Volberda et al. (2010), strategic management based on long-term forecasts, helps the company to anticipate future challenges and opportunities. Such documents deal with important areas of enterprise organization such as human resources, market analyses and marketing goals, product development and innovation, technologies of production and services, logistics, quality and environment, budgeting, financing and payback, time schedule, risk evaluation, etc. The benefits of this strategic management is that it determines the strengths and weaknesses of the company, it also emphasizes those that are 
strategically important for the company's activities, and contributes to setting the right goals of the company. (Robinson, 2021).

Entrepreneurs may be considered risk takers and innovators, but they are not always strong supporters of strategic planning, especially in smaller businesses. Nonetheless, small business entrepreneurs also will have to experience the uncertain future. Strategic planning has one significant factor which is to come up with ways in order to face that uncertainty. (Foster, 1993).

A business plan is one of the main things that can help a business thrive. It should include the summary of what the business does, how it was developed and where it wants to be in the future. Use targets to implement your business plan. A successful business plan needs to include its targets and objectives. Targets make it clearer to the employees on what they need to do to help the business meet its objectives (Crown, 2009). Always refer to the original vision of your business plan. It is important to the company to go back to the belief of the business plan that they started with. The plans written will keep you grounded and it will help the business avoid such obstacles that may come its way. (Scholtz, 2019).

\section{Entrepreneurial Trials:}

The rate of failures and discontinuances among small businesses is high especially during the first few years after start-up. Business failures are often the result of management concerns, especially when it comes to areas regarding poor financial management and undercapitalization. Moreover, these problems during an enterprise's life can cause more conundrums for their owners. Many colleges of business have established entrepreneurship and small business classes and programs to prepare students for careers as entrepreneurs and in small business. (Dunn \& Liang, 2011) While entrepreneurial business issues and obstacles that immigrant entrepreneurs confront have not been studied extensively, many agree that the adequate funding start-up and develop their businesses from financial institutions is an utmost importance, especially since most of their capital financing come from their families and friends (Alam\&Hoque, 2010; Desiderio, 2014; Sanders \& Nee, 1996; Nel\& Abdullah, 2017). Low educational level and lack of prior experience are among the factors that decrease their chances to obtain financial aid, especially from public financial institutions (Bewaji, Yang, \& Han, 2015; Nel\& Abdullah, 2017).

Dauntingly, business owners in the competitive market are relentless and unsparing. Businesses and firms that are usually at the top are neck-and-neck, in terms of competition and innovation. Being a part of the same competitive market, small businesses could and would struggle to compete with other competitors, especially if innovation among competitors is constantly growing and improving.It is more likely that firms operating in economies where the competition policy is more effectively enforced would be innovative. However, there is a point where "too much' competition leads to less innovation - suggesting a tipping point effect (Crowley \& Jordan, 2016). The relationship between the intensity of competition and innovation proves to be of inverted U-shape. Furthermore, there is evidence for the relationship being steeper for neck-and-neck industries in accordance with the major theoretical postulates (Brodzicki, 2018).

Competition can lead to an expansion in aggregate employment whenever it significantly reduces the aggregate price level. This happens when the increase in competition happens simultaneously across sectors (Maggi \& Felix, 2019). Competition among the ecosystems of businesses is a brawl for market share. But below the surface, these new struggles of competitiveness are fights that would eventually determine on who will direct the future (Moore, 1999).

In every business, it is critical to weigh things between doing good or bad for the betterment of the enterprise's welfare and common good. Financial crisis is defined as the depreciation of the exchange rate or stock market decline. (Anh, Thuy, \&Khanh, 2018).

Financial crises are inherently hard to predict. If they could be predicted easily, they could be avoided or immediately triggered (Neely, 2011). In a way, we need to be alert in every move we do in making the business standby, we find that it is easier to predict changes in demand for external finance than it is to predict changes in the supply of external funds during a recession (Cowling, Liu \& Ledger, 2012).

Experiences regarding financial crises have lasting consequences. Americans reported sharp declines in their life evaluation, sharp increases in worry and stress, and declines in positive affect (Deaton, 2012). In addition, the main 
cause of financial crises is arising debts. Most financial crises are a result of the rational or irrational behavior of participants in financial markets including debt markets, equity markets, and derivatives markets (Ozili, 2020).

A small business can hold a unique characteristic that can produce the same set of financial problems in a different manner. If there are problems to solve, there are some situations that we need to face such as consequences, different financial decisions, types of financial arrangements, institutions, and practices may evolve. (Ang, 1991)

In a business, it is normal to express concern about something being done correctly in order to seek common goods and welfare. Management, in particular, can be concerned with both nonfinancial and financial aspects of business in every trial we've faced including the environment in which business operates (Weiss, 2014).

Some businesses are increasing towards the trends that may lead to increasing the interest in the field of workflow management. It may provide a perspective in the system and think of possible future research direction or commerce solutions within the area (Basu\& Kumar, 2002).

From small to medium enterprises, management can increase its productivity to achieve or obtain a specific objective for the organization that can improve its performance. From the management itself, it could build a relationship of both business skills and productivity with an atavism, also it brings a significant impact of productivity from small to medium enterprises (J. Pollack, D Adler, 2014).

A strategic management can outline a new set of objectives in a different perspective. This perspective can help us explore and identify the key issues and gaps of what needs to be improved and studies for future practices and performance in a firm (Sharma et. al., 2004).

In pursuing different strategies in a firm, different kinds of knowledge management are being appropriately used but somehow the efforts don't always lead to improvement. Its priority literature of knowledge management is to use and develop arguments that can help also to identify the nature of management when it comes to business. Lastly, to be used to evaluate the stock market reaction to an organization. (Sabherwal,Sabherwal, 2007)

The top priority of most businesses is surpassing its own competition in the market. In some studies, there are different views of business process management issues that have across to different stakeholders to comprehend the gap. Some organizations have adapted the technologies of business process management because of a personal perspective (Sadiq et al, 2007).

\section{Entrepreneurial Solutions:}

There are reasons to believe that a business is considered a failure. It could be compared to living beings: one day, they are born, and sooner or later, they perish (Fridenson, 2004). Business losses occur when a business goes bankrupt, and in turn, closes, whether it be for financial reasons, performance issues, or other personal matters, such as family issues, retirement, and other similar cases (Dias \& Teixeira, 2017).

Coping is the process of managing taxing circumstances, expanding efforts to solve personal and interpersonal problems, seeking to master, minimize, reduce, tolerate, or eradicate stress induced by unpleasant and stressful situations (Weiten\& Lloyd 2005; Wong, Yik\&Kwong 2006; Drnovšek, Örtqvist, \&Wincent; 2010). Coping is done to master the conditions, which are perceived to be harmful, threatening or challenging consisting of intrapsychic or action-oriented efforts to manage the internal or external demands and conflicts (Lazarus \&Launier, 1978; Dhawan, 2017). Tsarenko\&Strizhakova (2013) state that coping comes with numerous complexities and dimensionsThe manner of coping is typically complex and multi-dimensional. Early work of Folkman and Lazarus (1980) differentiated problem focused coping and emotion focused coping, but then noted that these do not rival, but complement each other (Lazarus, 1996; Charsetad, Vazifehdoost, \&Nikoomaram, 2016).

There are two major kinds of coping; problem-focused and emotion-focused coping. Problem-focused coping is managing, or changing a problem causing distress while emotion focused coping regulates emotional reactions to a problem. This nomenclature of problem focused and emotion focused coping proved to be a good place to start categorizing individual's coping behavior even though some researchers have criticized these two categories as an oversimplification of coping strategies (Folkman et al. 2004; Singh, Corner, \& Pavlovich, 2007). Coping style, as evidenced through dispositional versus situational coping (Bouchard et al.2004; Boxer, Sloan-power, Mercado, 
\&Schappell, 2012). Dispositional training (also known as trait coping) refers to someone's coping style in response to different stressful situations, while situational coping refers to the potential to experiment with more dynamic applications for coping styles. These two types of coping are not exclusive concepts - as supported by Bouchard et al. (2004), who discovered evidences supporting mediated effects of dispositional coping on outcomes through situational coping - but they raise challenges for research implications on youth coping for distractions that rely on education regarding this topic, which can help reduce or prevent issues regarding mental health (Boxer, Sloanpower, Mercado, \&Schappell, 2012).

Moreover, motivation is considered a necessary workplace instrument. Hence, there is a noticed challenge in newer organizations once its employees are motivated. The self-determination theory (SDT) shows the differences between autonomous and controlled motivation. Autonomous motivation displays a person's power to choose, while controlled motivation is observed when someone is faced with challenges (Reizer, Brender-Ilan, \&Sheaffer, 2019). The theory states that job satisfaction is heavily impacted by personal motivation (Smokrović et al., 2019). Motivation can also be defined as the ideal construct used to identify forces that establish an individual's certain behaviors (Vallerand \&Thill, p. 18, translated from French; Vallerand, 2012).

Professional literature (Hessami - Moore, 2007; Marosi\&Katona, 2015) states that people show competence once they gain experience and/or professional wisdom and capabilities in order to execute tasks accurately. In other words, they are expected to know what they are doing (Bencsik, 2014; Marosi\&Katona, 2015).

There are numerous reasons as to why someone decides to pack their bags and work in another country. For one, it is now considered a common practice for hiring and deploying personnel to search for potential employees across national borders. Initiation of employment may be done either by the employer or the individual themselves. Other reasons include reconnection with loved ones in a different location, opportunity seizing, refuge from war or crises, seeking adventure, and other similar reasons. (Supangco\&Mayrhofer, 2014).

The Philippines is constantly ranked in the top five countries that provide immigrants who fly to the United States over the course of twenty years (McNamara \&Batalova, 2015; Zong\&Batalova, 2018; Gabriel, 2019). In terms of immigration, the relationship between the Philippines and the United States dates back to the fifty-year colonization of the Americans in the Philippines, which was when the American-modeled schools were established and the English language was taught, replacing the Catholic conversion, which occurred during the 300-year Spanish colonization (Espiritu, 1995; Gabriel, 2019), which could have led to a proper acculturation methodology for Filipino-Americans and an invisible barrier (Gabriel, 2019).

Maintaining a high level of motivation at different ages is necessary in order to succeed in dealing with changes in work potential (Stamov-Roßnagel and Hertel, 2010;Rožman, Treven, \&Čančer, 2017) Career motivation is something that is dependent on the individual's influences (Ortiz, 2015; Mustapa, Noor, \&Mutalib, 2019). It can also be defined as the characteristics associated with employment decisions and behaviors (London, 1983; Peters et al., 2014; Mustapa, Noor, \&Mutalib, 2019). It is a multidimensional construct which focuses on the following major domains: (1) career identity, which is the motivation related to how an employee identifies themselves in the workplace, (2) career resilience, which refers to the maintenance of the motivation that they have established by adapting to constant change, and (3) career insight, which refers to the strengthening of motivation through means of clarifying an individual's career goals. Another way for an employee to display their motivation and dedication is to work hard, show pride, and view themselves as experts (Alniacik, Alniacik, Kultigin, \&Erat, 2012; Mohammed et al., 2014; Zoogah, 2013; Mustapa, Noor, \&Mutalib, 2019)

Furthermore, in order to achieve economic survival, it requires a strong bond and networks with one's family, neighborhood, and culture. While considering poverty's extensiveness, the family represents resources and governance (Petersen \&Charman, 2018) Family motivation can be defined as the desire to continue exerting efforts in order to benefit one's family. Hence, it can be classified as a benevolent encouragement, since the individual's own family is considered their beneficiary. It is likely more understood when a family is depending on the individual at home, but it is commonly accepted that family is only composed of a person, his/her spouse, and their children, which is false. An individual's family can be extended to other members such as grandparents, in-laws, cousins, and the like (Burnstein, Crandall, \&Kitayama, 1994; Menges et al., 2017). 
It is understood that people perform at least two different roles in life: one within their own families, and the other in the workplace. Their performances vary on each platform. When these roles are combined, it is observed that family motivation positively affects people's performance in their jobs. As the job performance of a person is reliant of numerous things (e.g. self-motivation, environment, colleagues, benefits, and the like), there is a hypothesis that the thought of working for their families helps employees increase energy, maintain focus and reduce stress (Rafique\& Jawad, 2019). However, on another argument, family motivation encourages employees to see their jobs as a way of gaining financial support for their families rather than seeing their jobs as an end itself. It can be associated with lower levels of creativity (Zhang, Li, \& Colbert, 2020). Additionally, another study revealed that family motivation does not positively affect employees' organizational citizenship behavior-individual (OCBI). Instead, the relationship is fully reliant on their own efficacy (Waheed et al., 2020).

\section{Conclusion:-}

The Philippines is one of the countries in the world that can be considered as the origin for employees, thus a lot of Filipinos are being sought after in so many job seeking companies not only in the Philippines, but also abroad. Moreover, a lot of Filipinos choose to work overseas in order to provide for their families back in the Philippines. However, it is evident that the income that they gain from their employment situations do not exactly meet their family's needs. As a result of this conundrum, some resort to searching for possible entrepreneurship endeavors in order to help sustain their families back at home.

Besides the need to satisfy their own family's needs and wants, some Filipino migrant workers also tend to raise businesses simply because they show passion in the endeavor. Another reason why they might decide on raising an enterprise is for them to save up some money for future purposes. Furthermore, they also plan on committing to maintaining the business, keeping it afloat in order for them to have a guaranteed source of income once they plan on retiring in the foreseeable future.

Starting a business may seem easy, but maintaining it is easier said than done. Along the way, it is expected that there would be numerous hurdles that one has to overcome in order to maintain their business. Such issues include: (1) management issues, which refer to all the management-related issues that caused the business to crumble, (2) competition issues, which refer to all the issues regarding emerging competition which negatively impacted the business one raised, and (3) financial burdens, which refer to the overwhelming debts, taxes, and other liabilities that a business has incurred over the course of its lifetime. As a result of these overwhelming trials, some decide that these complications are too much to handle, and they resort to closing their business entirely.

Losing a business has numerous consequences, and finding the perfect coping mechanism is not really easy, but it is doable. This phenomenological study was therefore conducted in order to determine the coping mechanisms of Filipino migrant workers who have experienced business loss at one point or another. The major coping mechanisms that emerged during this study were career motivation and family motivation.

For Filipinos, maintaining their status as an employee is necessary because they still need to provide for their families back in the Philippines. Moreover, being known for their family-orientedness, Filipinos turn to their family for motivation to go on with their lives.

Future researchers who plan on making a paper related to this study are recommended to consider other coping mechanisms in order to explore other options for future entrepreneurs. Furthermore, it is also recommended to focus on one type of business and one employment sector in order to achieve more specific findings.

\section{References:-}

1. Akin, H. B., \&Demirel, Y. (2015). Entrepreneurship Education and Perception Change: The Preliminary Outcomes of Compulsory Entrepreneurship Course Experience in Turkey/GirisimcilikEgitimive Algida Degisim: Türkiye'deZorunluGirisimcilikDersiDeneyiminin

Sonuçlari.SelcukÜniversitesiSosyalBilimlerEnstitüsüDergisi,

(34), 15-26.https://search-proquestcom.eres.qnl.qa/scholarly-journals/entrepreneurship-education-perception-change/docview/1768395812/se2? accountid $=49936$ 
2. Alnıaçık, Ü., Alnıaçı, E., Akçin, K., \&Erat, S. (2012). Relationships between career motivation, affective commitment and job satisfaction. Procedia-Social and Behavioral Sciences, 58, 355-362. Retrieved from https://www.sciencedirect.com/science/article/pii/S1877042812044734

3. Amankwah-Amoah, J. (2014). An integrative framework of attributions after a business failure. Retrieved fromhttps://ideas.repec.org/p/pra/mprapa/63384.html

4. Anderson, A. R., \&Gaddefors, J. (2017). Entrepreneurship and Context: Is entrepreneurship research out of context? Dilemmas with (non) contextualised views of entrepreneurship. Journal of Asia Entrepreneurship and Sustainability, 13(4), 3-9.https://search-proquest-com.eres.qnl.qa/scholarly-journals/entrepreneurship-contextis-research-out-dilemmas/docview/2007939429/se-2?accountid=49936

5. Ang, J. S. (1991). Small business uniqueness and the theory of financial management. Journal of small business finance, 1(1), 1-13. Retrieved from https://www.econstor.eu/handle/10419/114623

6. Baker, W. H., Addams, H. L., \& Davis, B. (1993). Business planning in successful small firms. Long range planning, 26(6), $\quad$ 82-88. Retrieved fromhttps://www.sciencedirect.com/science/article/abs/pii/002463019390209X

7. Basu, A., \& Kumar, A. (2002). Research commentary: Workflow management issues in e-business. Information Systems Research, 13(1), 1-14. Retrieved fromhttp://citeseerx.ist.psu.edu/viewdoc/download?doi=10.1.1.90.4428\&rep=rep1\&type=pdf

8. Bautista, A.G.M. and Tamayo, V.T. (2020) Life Challenges of Overseas Filipino Workers. Open Access Library Journal, 7, 1-9. doi:10.4236/oalib.1106854.

9. Boxer, P., Sloan-power, E., Mercado, I., \&Schappell, A. (2012). Coping with stress, coping with violence: Links to mental health outcomes among at-risk youth. Journal of Psychopathology and Behavioral Assessment, 34(3), 405-414. doi:http://dx.doi.org.eres.qnl.qa/10.1007/s10862-012-9285-6

10. Brodzicki, T. (2019). The intensity of market competition and the innovative performance of firms. Innovation, 21(2), 336-358. Retrieved from https://www.tandfonline.com/doi/abs/10.1080/14479338.2018.1532296

11. Charsetad, P., Vazifehdoost, H., \&Nikoomaram, H. (2016). Coping behaviors V.S customer complaint behavior: A study of iranian consumers 'coping behaviors with service failures: Revistabrasileira de marketing revistabrasileira de marketing.REMark, 15(5), 566-n/a. Retrieved from https://search-proquestcom.eres.qnl.qa/docview/1872908944?accountid=49936

12. Connelly, L. M. (2010). What is phenomenology? Medsurg Nursing, 19(2), 127-8. Retrieved fromhttps://search-proquest-com.eres.qnl.qa/docview/230522357?accountid=49936

13. Crowley, F., \& Jordan, D. (2017). Does more competition increase business-level innovation? Evidence from domestically focused firms in emerging economies. Economics of Innovation and New Technology, 26(5), 477488. Retrieved fromhttps://www.tandfonline.com/doi/abs/10.1080/10438599.2016.1233627

14. Cybal-Michalska, A. (2020). The Reality of the Globalizing World and Shaping the Professional Iden. SpringerLink. https://link.springer.com/chapter/10.1007\%2F978-3-030-51549-2_74

15. Dhawan, N. (2017). COPING MECHANISM TO MANAGE STRESS: AN EMPIRICAL ANALYSIS. Delhi Business Review, 18(2), 87-96. Retrieved fromhttps://search-proquestcom.eres.qnl.qa/docview/2001313203? accountid $=49936$

16. Dias, A., \& Teixeira, A. A. C. (2017). The anatomy of business failure: A qualitative account of its implications for future business success. European Journal of Management and Business Economics, 26(1), 2-20. doi:http://dx.doi.org.eres.qnl.qa/10.1108/EJMBE-07-2017-001

17. Drnovsek, M., Örtqvist, D., \&Wincent, J. (2010). The effectiveness of coping strategies used by entrepreneurs and their impact on personal well-being and venture performance*.ZbornikRadovaEkonomskiFakultet u Rijeka, 28(2), 193-220. Retrieved fromhttps://search-proquest-com.eres.qnl.qa/docview/851503721 ?accountid=49936

18. Dunn, P., \& Liang, K. (2011). A Comparison Of Entrepreneurship/Small Business And Finance Professors' Reaction To Selected Entrepreneurial And Small Business Financial Planning And Management Issues. Journal of Entrepreneurship Education, 14, 93-104. Retrieved fromhttps://search-proquestcom.eres.qnl.qa/docview/885241324?accountid $=49936$

19. Flota Rosado, J. A., \&Ocampo Figueroa, L. E. (2016). The Social Rewards for Mission-Driven Business: An Integrative Approach. Global Journal of Business Research, 10(4), 55-65. Retrieved fromhttps://papers.ssrn.com/sol3/papers.cfm?abstract id $=2926164$

20. Founders Guide. (2019, February 6). Planning Ahead for The Future of Your Business. Retrieved from https://foundersguide.com/planning-ahead-for-the-future-of-your-business/

21. Foster, M. J. (1993). Scenario planning for small businesses. Long Range Planning, 26(1), 123-129. Retrieved fromhttps://www.sciencedirect.com/science/article/abs/pii/002463019390240G 
22. Fridenson, P. (2004). Business Failure and the Agenda of Business History. Enterprise \& Society, 5(4), 562582. Retrieved fromhttps://search-proquest-com.eres.qnl.qa/scholarly-journals/business-failure-agendahistory/docview/218610347/se-2?accountid=49936

23. Friesen, W. (2017). Migration management and mobility pathways for Filipino migrants to New Zealand. Asia Pacific Viewpoint, 58(3), 273-288. Retrieved fromhttps://onlinelibrary.wiley.com/doi/abs/10.1111/apv.12168

24. Gabriel, M. G. (2019). Christian faith in the immigration and acculturation experiences of filipinoamerican youth. Journal of Youth Development, 14(2), 115-129.doi:http://dx.doi.org.eres.qnl.qa/10.5195/jyd.2019.710

25. Handy, C. (2002). What is a Business for?.SSRN. Retrieved fromhttps://papers.ssrn.com/sol3/papers.cfm?abstract id $=932676$

26. Hedley, G. (2017). How to Plan for Your Company's Future. Construction Business Owner Magazine. https://www.constructionbusinessowner.com/strategy/how-plan-your-companys-future

27. Hein, A., Weking, J., Schreieck, M., Wiesche, M., Böhm, M., \&Krcmar, H. (2019). Value co-creation practices in business-to-business platform ecosystems. Electronic Markets,29(3), 503-518. Retrieved fromhttps://link.springer.com/article/10.1007/s12525-019-00337-y

28. Hosain, S., \& Liu, P. (2020). LinkedIn for Searching Better Job Opportunity: Passive Jobseekers' Perceived Experience. The Qualitative Report, 25(10), 3719-3732. Retrieved from https://search-proquestcom.eres.qnl.qa/scholarly-journals/linkedin-searching-better-job-opportunity-passive/docview/2462684491/se$\underline{2}$ ?accountid $=49936$

29. Hussain, W. (2012). CORPORATIONS, PROFIT MAXIMIZATION AND THE PERSONAL SPHERE. Economics and Philosophy,28(3), 311-331. doi:10.1017/S0266267112000260. Retrieved fromhttps://www.cambridge.org/core/journals/economics-and-philosophy/article/abs/corporations-profitmaximization-and-the-personal-sphere/22ECD31895606D2F8868362FC208CB8D

30. Investor Relations: Business Strategy \& Future Plans. (n.d.). Riverstone Holdings Limited. http://riverstone.listedcompany.com/business_strategy.html

31. Iskandar, M. (2017). Perception of capital, profit and dividends affect the stock purchase intention in Indonesia public company. Junior Scientific Researcher, 3(1), 9-18. Retrieved fromhttps://www.ceeol.com/search/articledetail?id $=542289$

32. Jaffe, D. T. (2005). Strategic planning for the family in business. Journal of Financial Planning, 18(3), 50-56.

33. Jensen, M. (2002). Value Maximization, Stakeholder Theory, and the Corporate Objective Function. Business Ethics Quarterly,12(2), 235-256. Retrieved from doi:10.2307/3857812.https://www.cambridge.org/core/journals/business-ethics-quarterly/article/abs/valuemaximization-stakeholder-theory-and-the-corporate-objectivefunction/2A9534F1F514F341456BCC39DBFD419A

34. Johnson, J. P., Munoz, J. M., \&Alon, I. (2007). Filipino ethnic entrepreneurship: An integrated review and propositions. International Entrepreneurship and Management Journal, 3(1), 69-85. Retrieved fromhttps://link.springer.com/article/10.1007/s11365-006-0023-y

35. Johnson, M., C.P.A. (2019). How To Handle A Loss Of Business Income. Strategic Finance, 101(6), 19-20. Retrieved fromhttps://search-proquest-com.eres.qnl.qa/docview/2322070741 ?accountid=49936

36. Jones, T., \&Felps, W. (2013). Shareholder Wealth Maximization and Social Welfare: A Utilitarian Critique. Business Ethics Quarterly,23(2), 207-238. doi:10.5840/beq201323215.https://www.cambridge.org/core/journals/business-ethicsquarterly/article/shareholder-wealth-maximization-and-social-welfare-a-utilitariancritique/7DE15C85D4EF592FC3122C6770CB5BCA

37. Komatsu Cipriani, T., Deserti, A., Kleverbeck, M., Rizzo, F., \&Terstriep, J. (2020). Business models \& social innovation: mission-driven versus profit-driven organisations. International Review of Applied Economics, 34(5), 541-566.

38. Kuijpers, M. A. C. T., \&Scheerens, J. (2006). Career competencies for the modern career. Journal of career development, 32(4), 303-319. Retrieved from https://journals.sagepub.com/doi/abs/10.1177/0894845305283006

39. Lee, L., Wong, P. K., Der Foo, M., \& Leung, A. (2011). Entrepreneurial intentions: The influence of organizational and individual factors. Journal of business venturing, 26(1), 124-136.

40. Levinthal, D. A., \& Wu, B. (2010). Opportunity costs and non-scale free capabilities: profit maximization, corporate scope, and profit margins. Strategic Management Journal, 31(7), 780-801. Retrieved fromhttps://onlinelibrary.wiley.com/doi/abs/10.1002/smj. 845

41. Lindner, J. (2018). Entrepreneurship education for a sustainable future. Discourse and Communication for Sustainable Education, 9(1), 115-127. doi:http://dx.doi.org.eres.qnl.qa/10.2478/dcse-2018-0009 
42. Maggi, C., \&Feliz, S. (2019). What is the impact of increased business competition? International Monetary Fund. Retrieved fromhttps://sites.northwestern.edu/cmv468/files/2019/09/JMP_August19.pdf

43. MacLaren, S. A., "FJ" Maloney, Francis J, III, \& Phillips, C. M. (2017). Natural disasters and their implications on direct vs. indirect off-premises business income losses. The Brief, 46(3), 30-37. Retrieved fromhttps://searchproquest-com.eres.qnl.qa/docview/1923654987?accountid=49936

44. Mahto, R. V., \& McDowell, W. C. (2018). Entrepreneurial motivation: a non-entrepreneur's journey to become an entrepreneur. International Entrepreneurship and Management Journal, 114.http://dx.doi.org.eres.qnl.qa/10.1007/s11365-018-0513-8

45. Mannila, S., \&Eremicheva, G. (2018). Some risks of informal business in russia - a case study from saint petersburg. The International Journal of Sociology and Social Policy, 38(9), 823-836. doi:http://dx.doi.org.eres.qnl.qa/10.1108/IJSSP-06-2017-0084

46. Marosi, I., \&Katona, F. (2015). Examining Young Entrant Motivations and their Connection to the Learning Organization of Family Businesses. Management, Enterprise and Benchmarking in the 21st Century, , 321-338. Retrieved from_https://search-proquest-com.eres.qnl.qa/scholarly-journals/examining-young-entrantmotivations-their/docview/1945203351/se-2?accountid=49936

47. Massa, L., Tucci, C. L., \&Afuah, A. (2017). A critical assessment of business model research. Academy of Management Annals, 11(1), 73-104. Retrieved fromhttps://journals.aom.org/doi/abs/10.5465/annals.2014.0072\#

48. McNamara, K. \&Batalova, J. (2015). Filipino immigrants in the United States. Migration Information Source. Retrieved from http://www.migrationpolicy.org/article/filipino-immigrants-united-states-4

49. Menges, J. I., Tussing, D. V., Wihler, A., \& Grant, A. M. (2017). When Job Performance is All Relative: How Family Motivation Energizes Effort and Compensates for Intrinsic Motivation. Academy of Management Journal, 60(2), 695. Retrieved fromhttps://search-proquest-com.eres.qnl.qa/scholarly-journals/when-jobperformance-is-all-relative-how-family/docview/1905752601/se-2?accountid=49936

50. Moore, J. F. (1993). Predators and prey: a new ecology of competition. Harvard business review, 71(3), 75-86. Retrieved

fromhttps://www.researchgate.net/profile/James_Moore29/publication/13172133_Predators_and_Prey_A_New Ecology of_Competition/links/59a9ad2d0f7e9bdd114ac690/Predators-and-Prey-A-New-Ecology-of-

Competition.pdf

51. Mustapa, N. S., Noor, K. M., \&Mutalib, M. A. (2019). Social support and career motivation in public service. International Journal of Academic Research in Business and Social Sciences, 9(2). Retrieved fromhttps://www.researchgate.net/profile/Syifa_Mustapa3/publication/333259490_Social_Support_and_Career Motivation_In_Public_Service/links/5ce4b20ca6fdccc9ddc4b4d6/Social-Support-and-Career-Motivation-InPublic-Service.pdf

52. Needle, D., \& Burns, J. (2010). Business in context: An introduction to business and its environment. Boston: South-Western Cengage Learning. Retrieved fromhttps://www.edouniversity.edu.ng/oerrepository/articles/introduction to business _1_$\ln \_$fs_20182019.pdf

53. Nel, P., \& Abdullah, M. A. (2017). Mediating effects of business success on the relation between business issues and business prospects amongst immigrant entrepreneurs in malaysia. Contemporary Management Research, 13(1), 1-17. doi:http://dx.doi.org.eres.qnl.qa/10.7903/cmr.16380

54. Nititham, D. S. (2011). Migration as cultural capital: The ongoing dependence on overseas filipino workers. Malaysian Journal of Economic Studies, 48(2), 185-201. Retrieved from https://search-proquestcom.eres.qnl.qa/scholarly-journals/migration-as-cultural-capital-ongoing-dependence/docview/928761212/se2? accountid $=49936$

55. Novkovic, S. (2008). Defining the Co-operative Difference. The Journal of Socio-Economics, 37, 21682177. Retrieved fromhttp://dx.doi.org/10.1016/j.socec.2008.02.009

56. Osterwalder, A., \&Pigneur, Y. (2011). Aligning profit and purpose through business model innovation. Responsible management practices for the 21st century, 61-76. Retrieved fromhttps://discoversocialsciences.com/wp-content/uploads/2018/08/CANVAS-1.pdf

57. Petersen, L., \&Charman, A. (2018). The role of family in the township informal economy of food and drink in KwaMashu, South Africa. The International Journal of Sociology and Social Policy, 38(7-8), 564-577. Retrieved fromhttp://dx.doi.org.eres.qnl.qa/10.1108/IJSSP-06-2017-0068

58. Pollack, J., \& Adler, D. (2014). Does project management affect business productivity? Evidence from Australian small to medium enterprises. Project Management Journal, 45(6), 17-24. Retrieved fromhttps://journals.sagepub.com/doi/abs/10.1002/pmj.21459 
59. Pollard, C. W. (2017). The Role and Importance of Profit. Retrieved fromhttps://digitalcommons.spu.edu/pollard papers/185/

60. Prepare a Business Plan for Growth. (2009). Info Entrepreneurs. Retrieved fromhttps://www.infoentrepreneurs.org/en/guides/prepare-a-business-plan-for-growth/\#3

61. Quan, A. (2019, October 11). The 7 Steps to Business Planning Success. Small Business $B C$. https://smallbusinessbc.ca/article/7-steps-business-planning-success/

62. Rafique, T., Naeem, u. R., \& Jawad, R. A. (2019). Job Performance Dependence on Family Motivation for Energizing Efforts and Reducing Stress. The Journal of Humanities and Social Sciences, Xxvii(2), 181. Retrieved from https://search-proquest-com.eres.qnl.qa/scholarly-journals/job-performance-dependence-onfamily-motivation/docview/2475782472/se-2?accountid=49936

63. Reizer, A., Brender-Ilan, Y., \&Sheaffer, Z. (2019). Employee motivation, emotions, and performance: A longitudinal diary study. Journal of Managerial Psychology, 34(6), 415428.doi:http://dx.doi.org.eres.qnl.qa/10.1108/JMP-07-2018-0299

64. Roberts, J. S. (2012). Infusing Entrepreneurship within Non-business Discipline: Preparing Artists and Others for Self-Employment and Entrepreneurship.Artivate, 1(2), 53-63.https://search-proquestcom.eres.qnl.qa/scholarly-journals/infusing-entrepreneurship-within-non-business/docview/2451927246/se2? accountid $=49936$

65. Robinson, R. (1979). Forecasting and small business a study of the strategic planning process. Journal of Small $\begin{array}{lllll}\text { Business } \quad \text { Management } & \text { (pre-1986), } & 17(000003), & 19 . & \text { Retrieved }\end{array}$ fromhttps://search.proquest.com/openview/08e646449575a85a263e07d97b3ff6d5/1?pqorigsite $=$ gscholar\&cbl $=49243$

66. Robson, G. (2019). TO PROFIT MAXIMIZE, OR NOT TO PROFIT MAXIMIZE: FOR FIRMS, THIS IS A VALID QUESTION. Economics and Philosophy,35(2), 307-320. doi:10.1017/S0266267118000329. Retrieved fromhttps://www.cambridge.org/core/journals/economics-and-philosophy/article/abs/to-profit-maximize-or-notto-profit-maximize-for-firms-this-is-a-valid-question/A151C7B63A4E7A4E2D0DA72FA01A6B67\#accessblock

67. Rožman, M., Treven, S., \&Čančer, V. (2017). Motivation and Satisfaction of Employees in the Workplace. Business Systems Research, 8(2), 14-25.http://dx.doi.org.eres.qnl.qa/10.1515/bsrj-2017-0013

68. Sabherwal, R., \&Sabherwal, S. (2007). How do knowledge management announcements affect firm value? A study of firms pursuing different business strategies. IEEE Transactions on Engineering Management, 54(3), 409-422. Retrieved fromhttps://ieeexplore.ieee.org/abstract/document/4278017

69. Sadiq, S., Indulska, M., Bandara, W., \& Chong, S. (2007). Major issues in business process management: A vendor perspective. In Managing Diversity in Digital Enterprises: Proceedings of the 11th Pacific Asia Conference on Information Systems (pp. 40-47). The University of Auckland, School of Business. Retrieved fromhttps://eprints.qut.edu.au/15572/1/15572.pdf

70. Sajilan, S., UlHadi, N., \&Tehseen, S. (2015). Impact of entrepreneur's demographic characteristics and personal characteristics on firm's performance under the mediating role of entrepreneur orientation. Review of Integrative Business and Economics Research, 4(2), 36-52. Retrieved fromhttps://search-proquestcom.eres.qnl.qa/docview/1690045882?accountid $=49936$

71. Scholtz, P. (2019). The Future of the Business Plan. Entrepreneur South Africa. Retrieved from https://www.entrepreneur.com/article/326907

72. Seltzer, J. A. (2019, March 5). Family Change and Changing Family. Springer Link. https://link.springer.com/article/10.1007/s13524-019-00766-6?error=cookies_not_supported\&code=8d8f2abc8a1a-44f8-878f-f7c28200081d

73. Sharma, P., Chrisman, J. J., \& Chua, J. H. (1997). Strategic management of the family business: Past research and future challenges. Family business review, 10(1), 1-35. Retrieved fromhttps://onlinelibrary.wiley.com/doi/abs/10.1111/j.1741-6248.1997.00001.x

74. Singh, S., Corner, P., \& Pavlovich, K. (2007). Coping with entrepreneurial failure. Journal of Management and Organization, 13(4), 331-344. Retrieved fromhttps://search-proquestcom.eres.qnl.qa/docview/233253125?accountid $=49936$

75. Smokrović, E., Žvanut, M. F., Bajan, A., Radić, R., \&Žvanutb, B. (2019). The effect of job satisfaction, absenteeism, and personal motivation on job quitting: A survey of croatian nurses *. Journal of East European Management Studies, 24(3), 398-422.doi:http://dx.doi.org.eres.qnl.qa/10.5771/0949-6181-2019-3-398

76. Supangco, V., \&Mayrhofer, W. (2014). Determinants of work role transition outcomes of Filipinos in Singapore. Journal of Global Mobility, 2(3), 317-342. http://dx.doi.org.eres.qnl.qa/10.1108/JGM-07-2013-0048 
77. Skokan, K., Pawliczek, A., \&Piszczur, R. (2013). Strategic planning and business performance of micro, small and medium-sized enterprises. Journal of competitiveness, 5(4).

78. Tsarenko, Yelena \&Strizhakova, Yuliya. (2013). Coping with service failures: The role of emotional intelligence, self-efficacy and intention to complain. European Journal of Marketing. 47. $10.1108 / 03090561311285466$.

79. Ucbasaran, D., Shepherd, D. A., Lockett, A., \& Lyon, S. J. (2013). Life After Business Failure: The Process and Consequences of Business Failure for Entrepreneurs. Journal of Management, 39(1), 163202.https://doi.org/10.1177/0149206312457823

80. ÜmitAlnıaçık, EsraAlnıaçı, KültiginAkçin, SerhatErat, Relationships Between Career Motivation, Affective Commitment and Job Satisfaction, Procedia - Social and Behavioral Sciences, Volume 58, 2012, Pages 355362, ISSN 1877-0428,https://doi.org/10.1016/j.sbspro.2012.09.1011.

81. Umrani, W.A., et al. (2019), Does family come first? Family motivation-individual's OCB assessment via selfefficacy, Personnel Review, Vol. 49 No. 6, pp. 1287-1308. https://doi.org/10.1108/PR-01-2019-0031

82. Uy-Tioco, C. (2007) Overseas Filipino Workers and Text Messaging: Reinventing Transnational Mothering. Journal of Media \& Cultural Studies, 21, 253-265.https://doi.org/10.1080/10304310701269081

83. Vallerand, R. J. (2012). From motivation to passion: In search of the motivational processes involved in a meaningful life. Canadian Psychology, 53(1), 42-52. Retrieved from https://search-proquestcom.eres.qnl.qa/scholarly-journals/motivation-passion-search-motivational-processes/docview/924230210/se2?accountid $=49936$

84. Villalba, M.A. (2012). Benefits and Challenges of Entrepreneurial Literacy in the Philippines. DVV International, Journal AED - Adult Education and Development. Retrieved fromwww.dvvinternational.de/en/adult-education-and-development/editions/aed-782012/benefits-of-adult-learning-andsocial-inclusion/benefits-and-challenges-of-entrepreneurial-literacy-in-the-philippines

85. Waheed, A. U., Imdad, A. S., Ahmed, U., Ghulam, A. A., Sayed, H., \&Umrani, S. (2020). Does family come first? Family motivation-individual's OCB assessment via self-efficacy. Personnel Review, 49(6), 1287-1308. http://dx.doi.org.eres.qnl.qa/10.1108/PR-01-2019-0031

86. Weiss, J. W. (2014). Business ethics: A stakeholder and issues management approach. Berrett-Koehler Publishers.

Retrieved fromhttps://books.google.com.qa/books?hl=en\&lr=\&id=gMUlAgAAQBAJ\&oi=fnd\&pg=PT19\&dq=manageme $\underline{\mathrm{nt}}+$ issues + in + business\&ots $=$ Wt5Zgm15a1\&sig $=\mathrm{w}-$ 4xftGH8ljRIcv5U1_Sw30L5wc\&redir_esc $=\mathrm{y} \# \mathrm{v}=$ onepage \&q= management $\% 20$ issues $\% 20 \mathrm{in} \% 20 \mathrm{business} \& \mathrm{f}=\mathrm{fal}$ $\underline{\mathrm{se}}$

87. Williams, C. (2019). How to Plan for Your Company's Future. Synecticsworld. Retrieved from https://synecticsworld.com/how-to-plan-for-your-companys-future/

88. Zelekha, Y., Yaakobi, E., \&Avnimelech, G. (2018). Attachment orientations and entrepreneurship. Journal of Evolutionary Economics, 28(3), 495-522. doi:http://dx.doi.org.eres.qnl.qa/10.1007/s00191-018-0570-8

89. Zong, J. \&Batalova, J. (2018). Filipino immigrants in the United States. Migration Information Source. Retrieved from http://www.migrationpolicy.org/article/filipino-immigrants-united-states

90. Zhang, X., Liao, H., Li, N., \& Colbert, A. E. (2020). Playing It Safe for My Family: Exploring the Dual Effects of Family Motivation on Employee Productivity and Creativity.Academy of Management Journal, 63(6), 1923. http://dx.doi.org.eres.qnl.qa/10.5465/amj.2018.0680. 